\title{
KEEFEKTIFAN MODEL SCRAMBLE TERHADAP HASIL BELAJAR SISWA PADA PEMBELAJARAN IPA
}

\author{
Ninda Erni Apriyanti \\ Fakultas IImu Pendidikan, Universitas PGRI Semarang, \\ e-mail: Nindaerni64@gmail.com
}

\begin{abstract}
ABSTRAK
Penelitian ini bertujan untuk meningkatkan hasil belajar siswa khusunya dalam pembelajaran IPA.namun pada kenyataannya yang ada di SD Negeri 03 kedalon kecamatan batangan kabupeten pati pada pembelajaran IPA masih menggunakan model pembelajaran yang konvensional selain itu ada beberapa siswa yang belum memahami materi dalam mata pelajaran IPA. Hal ini berakibat terhadap hasil belajat IPA yang kurang memuaskan. siswa kelas IV SD Negeri 03 kedalon kecamatan batangan kabupaten patiterdapat 21 siswa dari jumlah siswa keseluruhan ada 16 siswa yang nilainya masih di bawah criteria ketuntasan minimal. Oleh karena itu diperlukan metode pembelajaran yang berbeda dari pembelajran yang konvesional. Salah satu model yang digunakan untuk meningkatkan hasil belajar dalam penelitian ini adalah model pembelajaran scramble. Dalam berbagai penelitian sudah banyak peneliti menggunakan model pembelajaran scramble salah satunya yang telah di uji oleh (sya'ban, 2016) dan dinyatakan berhasil.
\end{abstract}

Kata kunci : model scramble, hasil belajar.

\begin{abstract}
This research bertujan to increase yields of of students to study khusnya ipa.namun out of school in droves in reality there is there are in public primary schools 03 kedalon kecamatan bullion kabupeten starch on installations ipa as well as learning to promote disorder to still use learning model that is conventionally in addition there are several students who do not understand of its material in installations ipa as well as such as mathematics and science. This has resulted of the results of the belajat installations ipa as well as who as less than satisfactory. Student of class iv and private primary schools state 03 kedalon kecamatan bullion kabupaten patiterdapat 21 students from the number of students total are 16 of students who their score was less than is still under the ketuntasan would at least be the has to .For that reason there needs the learning methods he continued different from that of the pembelajran who of the conventional. One of its models that is used to improve learning outcomes in this research was kind of classroom scramble. In research on this topic is already a lot of researchers used kind of classroom scramble one of the ways is that which it had in the test and been approved by veni melia sya'ban( 2016 ) and was pronounced struggled to come to terms.
\end{abstract}

Keywords : scramble model, learning outcomes 


\section{Pendahuluan}

Pembelajaran IPA di SD, diupayakan adanya penekanan pada pembelajaran Salingtemas (Sains, lingkungan, teknologi, dan masyarakat) yang diarahkan pada pengalaman belajar yang lebih bermakna Depdiknas (dalam Citrasmi dkk, 2016). Depdiknas (dalam Andriana, 2014) menyatakan bahwa "Ilmu Pengetahuan Alam (IPA) berhubungan dengan cara mencari tahu tentang alam secara sistematis, dan IPA bukan hanya penguasaan kumpulan pengetahuan yang berupa fakta-fakta tetapi disertai dengan konsepkonsep, prinsip-prinsip yang merupakan suatu proses penemuan. Maka dapat disimpulkan bahwa mata pelajaran IPA adalah mata pelajaran yang penting, yang mana pelajaran IPA dipelajari sejak pendidikan dasar, pelajaran IPA digunakan siswa untuk mempelajari hubungan manusia dengan alam dengan cara. pengamatan dan pengumpulan konsepkonsep alam yang logis, sistematis dan bertujuan untuk sebuah penemuan.

Tujuan pembelajaran IPA di SD adalah pemahaman terhadap disiplin IPA dan keterampilan berkarya untuk menghasilkan suatu produk yang akan merefleksikan penguasaan kompetensi seseorang sebagai hasil belajarnya Sukra (dalam Citrasmi dkk, 2016). Maka terlihat pembelajaran IPA diorentasikan kepada aktivitas siswa dan guru yang mendukung konsep, prisip dan prosedur yang mendorong konsep pembelajaran yang bermakna untuk hasil yang memuaskan melihat rendahnya hasil-hasil belajar IPA siswa maka seorang pengajar perlu menggnakan model yang lebih efektif agar siswa termotivasi dalam belajar. Menurut Farida (2017) dalam hal menanggulangi permasalahan belajar dibutuhkan dorongan dan inspirasi untuk mengatasi masalah tersebut dengan menggunakan strategi pembelajaran yang inovatif dan menciptakan situasi baru yang menyenangkan yaitu suatu model yang dapat diterapkan dalam proses pembelajaran untuk meningkatkan kemampuan berpikir kritis siswa.Salah satu model yang dinilai lebih efektif dan mampu memotivasi siswa dalam belajara mata pelajaran IPA adalah model pembeljaran kooperatif tipe scramble.

Scramble tampak seperti model pembelajaran word square, bedanya jawaban soal tidak dituliskan di dalam kotak-kotak jawaban, tetapi sudah dituliskan namun dengan susunan yang acak, siswa bertugas mengkoreksi (membolak-balik huruf) jawaban tersebut sehingga menjadi jawaban yang tepat dan benar (Kahfi, 2013). Scramble adalah model pembelajaran yang mengajak siswa akan mencari jawaban terhadap suatu pertanyaan atau pasangan dari konsep secara kreatif dengan cara menyusun huruf - huruf, yang disusun secara acak sehingga membentuk suatu jawaban atau pasangan konsep yang dimaksud (Ningtyas, 2018). Model Scramble mengajak siswa untuk menyelesaikan permasalahan yang ada dengan cara membagikan lembar soal dan lembar jawaban yang telah disertai dengan alternatif jawaban yang tersedia (Himawati, 2017).

Keefektifan penggunaan dari pembelajaran kooperastif tipe scramble didukung dengan penelitian yang dilakukan oleh Veni Melia Sya'ban (2016) menunjukkan bahwa penerapan model pembelajaran kooeratif tipe scramble dapat meningkatkan minat belajar siswa dalam pembelajaran IPS. Selain itu berdasarkan penelitian yang dilakkan oleh Sudarmi dan Baharudin (2017) mennnjukkan bahawa penggunaan model pembelajran kooperatif tipe scramble efektif ntuk meningkatkan keterampilan menulis kalimat bahasa jerman.

Berdasarkan hasil observasi dan wawancara dengan guru kelas IV SD Negeri 03 kedalon kecamatan Batangan kabuaten Pati moel pembelajran yang digunakan masih menggunakan model konvensional sehingga ada beberapa siswa yang kurang memehami materi yang disampaikan oleh guru. Akibatnya hasil belajar yang diperoleh siswa khususnya pada pelajaran IPA belum memenuhi kriteria ketuntasan minimal.

\section{Metode}

Dalam peneletian ini peneliti menggunakan model pembelajaran yang berbeda dengan model konvesiaonal. Model yang digunakan harus melibatkan siswa untuk belajar aktif salah satunya yatiu model pembelajaran scramble merupakan salah satu model pembelajaran yang melibatkan beberapa siswa dalam bekerjasama menjawab pertanyaan yang diberikan 
oleh guru dengan cara menyusun huruf menjadi kata, kata menjadi kalimat, atau kalimat yang teracak menjadi sebuah paragraph yang utuh dan bermakna.menurut Susanto (2018) hasil belajar (learning outcomes) adalah kemapuan yang diperoleh siswa selama melakukan kegiatan belajar. Kemampan yang diperoleh itu menyangkut pengetahuan, pengertian, dan pekerjaan yang dapat dilakukan oleh siswa. Dalam konteks pendidikan formal pada umumnya dinyatakan bahwa hasil belajar adalah pernyataan yang mendeskripsikan pengetahuan, sikap, dan keterampilan yang dimiliki siswa setelah menempuh pelajaran tertentu. Dalam perkembangan dunia pendidikan, ranah pengetahuan atau ilmu pengetahuan sering dikonotasikan sebagai ranah kognitif. Namun dapat juga dikonotasikan lain, misalnya keterampilan proses ilmiah. Hal ini ditekankan untuk memperbaiki pemahaman dan kebiasaan yang menjurus pada pengertian bahwa ranah pengetahuan adalah ranah yang menyangkut kemampan menghafal pengetahuan sebagai produk ilmiah. Adapun hasil belajar tidak hanya berupa hafalan terhadap pengetahan ilmiah yang bersifat verbal, tetapi siswa juga dapat mencapai perkembangan kognitif,serta menguasai keterampilan proses ilmiah, sikap, keterampilan motorik, dan kecakapan hidup.

Penelitian yang dilakukan penulis merupakan penelitian kuantitatif dengan metode eksperimen "pre-experimental design " (non design). Metode penelitian eksperimen dapat diartikan sebagai metode penelitian yang digunakan untuk mencari pengaruh perlakuan tertentu terhadap yang lain dalam kondisi yang terkendalikan (Sugiyono,2015:72). Penelitian ini menggunakan jenis-jenis one-Group Pretest Posttest design dengan maksud untuk membandingkan apakah hasil belajar siswa meningkat atau tidak pada kelas IV SDN Kedalon 03 Kecamatan Batangan Kabupaten Pati. Peneliti memberikan pretest sebelum memberikan perlakuan yaitu menggunakan model pembelajaran scramble kemudian memberiakan posttest setelah diberiperlakuan menggunakan model pembelajaran scramble.

\section{Hasil dan Pembahasan}

Berdasarkan perhitungan analisis statistic pada paparan di atas, maka didalam pembahasan ini akan dijelaskan mengenai hasil dari analisis data yaitu: data tes yang digunakan dalam bentuk pretest dan posttest. Rancangan penelitian atau design penelitian yaitu pola yang menggambarkan bagaimana penelitian melakukan analisis terhadap data atau fakta yangbtelah dikumpulkan.

Metode penelitian yang di gnakan adalah penelitian metode eksperimen "preexperimental design " dengan jenis one groub pretest dan posttest yait terdapat pretest, sebelum diberikan perlakuan. Peneliti mengambil sat kelas yang berdistribusi normal. Penelitian ini dilakukan terhadap siswa kelas IV SDN 03 Kedalon Kecamatan Batangan Kabupaten Pati dengan jmlah siswa 22. Ada tahap sebelumnya diberi perlakuan, terlebih dahulu dilakakn uji noermalitas awal dengan menggunakan pretest. Uji normalitas dilakukan untuk mengetahui subjek penelitian berdistribusi normal atau tidak normal. Berdasarkan perhitungan yang telah dilakkan diperoleh kesimpulan bahwa nilai pretest kelas IV SDN 03 Kedalon Kecamatan Batangan Kabupaten Pati bersistribsi normal karena $<$ nilai $\quad=0,19$ dengan ó $=5 \%$, nilai 0,13 penelitian ini menggnakan model scramble . pada tahap akhir dilakkan kembali uji normalitas dengan menggunakan posttest. Berdasarkan perhitungan diperoleh $=0,91$ dengan $\alpha=5 \%$, nilai $=0,11$, karena < maka disimpulkan bahwa kelas tersebut berdistribusi normal. Dari data uji normalitas menggnakan uji liliefors untk nilai pretest dan posttest pada kelas IV SD N 03 Kedalon Kecamatan Batangan Kabupaten Pati memenuhi criteria pengjian yaitu < perhitungan diperoleh bahwa hasil nilai posttest lebih baik dari nilai pretest, hal ini menunjukkan bahwa sampel kelas eskperimen berdistribusi normal.

Sedangakan untuk rata-rata nilai tes sebelum diberi perlakan sebesar 61,3 dengan 6 siswa yang dinyatakan tntas dan 16 siswa yang dinyatakan tidak tuntas. Setelah dilakukan pembelajaran scramble dengan model scramble diperoleh rata-rata posttest sebesar 83,4 dengan 22 siswa yang dinyatakan tuntas. Presentase kenaikan hasil belajar sebesar $73 \%$. Hal ini diperkuat dengan uji t hasil belajar diperoleh 16,369 maka hal ini menunjukkan bahawa uji thasil belajar ada perbedaan signifikan. Meningkatnya nilai rata-rata hasil belajar 
IPA materi gaya dikarenakan pada proses pembelajaran menggnakan model pembelajaran scramble. Hasil temuan dalam penelitian ini sejalan dengan penelitian yang dilakukan oleh Ramadani (2014) dengan judul "Pengaruh Model Pembelajaran Kooperatif Tipe Scramble Berbantuan Kartu Pertanyaan terhadap Hasil Belajar IPA Siswa Kelas V SD" yaitu penerapan model pembelajaran kooperatif tipe scramble dalam pembelajaran IPA dapat meningkatkan hasil belajar siswa. Hasil ini dibuktikan dari rata-rata hasil belajar IPA siswa dengan model scramble adalah 77,05 dan rata-rata skor hasil belajar IPA dengan pembelajaran konvensional adalah 69,21. Hal ini berarti bahwa rata-rata eksperimen lebih besar rata-rata kontrol.

Hasil temuan dalam penelitian ini diperkuat dengan penelitian yang dilakukan oleh Citrasmi (2016) yang menunjukkan bahwa rata-rata skor hasil belajar IPA kelompok siswa yang dibelajarkan dengan model pembelajaran scramble sebesar 25,27 dan rata-rata skor kelompok yang dibelajarkan dengan model pembelajaran konvensional adalah 17,13. Hal ini berarti bahwa rata-rata eksperimen lebih besar rata-rata kontrol, sehingga dapat disimpulkan bahwa penerapan model pembelajaran scramble berbantuan media gambar berpengaruh positif terhadap hasil belajar IPA siswa kelas IV di SD Negeri 1 Semarapura Tengah Kecamatan Klungkung. Hasil temuan tersebut menunjukkan bahwa penerapan model pembelajaran kooperatif tipe scramble berpengaruh positif terhadap hasil belajar IPA. Penelitian oleh Andriyani (2018) menunjukkan bahwa terdapat perbedaan yang signifikan hasil belajar IPA siswa antara kelompok siswa yang dibelajarkan dengan model pembelajaran kooperatif tipe scramble berbantuan LKS dan kelompok siswa yang dibelajarkan dengan pembelajaran konvensional pada siswa kelas V Semester II di SD Gugus XIV Kecamatan Buleleng Tahun 2017/2018. Hasil penelitian ini menguatkan beberapa hasil penelitian yang ditemukan belakangan ini, diantaranya penelitian yang dilakukan oleh Artini (2013) dan Iryanti, Badruzzaman dan Sumardi (2013) menyatakan bahwa model pembelajaran kooperatif tipe scramble memberikan pengaruh yang positif terhadap hasil belajar IPS.

Pada saat penelitian juga mengalami beberapa kendala yang dialami oleh peneliti. Kendala yang terjadi saat berlangsungnya penelitian terjadi pada siswa yaitu interaksi social siswa yang kurang dimana saat pembentukan kelompok belajar siswa tidak menghendaki untuk dibentuk kelompok secara acak yang mana siswa memilih sendiri kelompok belajarnya. Hal tersebut dikarenakan saat dibentuk pembelajaran secara kelompok guru membiarkan terjadi penglangan dimana siswa memilih kelompok belajarnya sendiri. Selain itu saat siswa antusias dalam menyelesaikan soal menggunakan model pembelajaran scramble pengkondisian kelas sedikit susah dikendalikan karena terjadi suara gadhb saat siiswa berkelompok.

\section{Simpulan dan Saran}

Berdasarkan hasil penelitian yang dilakukan dapat disimpulkan bahwa penerapan model scramble dapat meningkatkan hasil belajar pada pembelajaran IImu Pengetahuan Alam materi gaya kelas IV SD N 03 Kedalon Kecamatan Batangan Kabupaten Pati. Hal ini terbukti pada analisis akhir dengan uji t di peroleh 16,369. Dari daftar distribusi t dengan db $=22-1=21$ dan tarafnya $5 \%$ diperoleh $=1,717$ karena kriteria pengujian $>$ maka diterima. Berdasarkan KKM yang di tentukan yaitu 70, rata-rata hasil belajar siswa yang diberikan perlakuan dengan menerapkan model scramble yaitu 83,45 telah mencapai KKM. Dapat disimpulkan terdapat peningkatan pada penerapan model scramble pada pembelelajaran IImu Pengetahuan Alam materi gaya terhadap hasil belajar siswa kelas IV SD N 03 Kedalon Kecamatan Batangan Kabupaten Pati.

\section{Daftar Pustaka}

Andriyani, P. I. , I M. Tegeh, I W. Suwatra. 2018. Pengaruh Model Pembelajaran Kooperatif Tipe Scramble Berbantuan LKS Terhadap Hasil Belajar IPA. Jurnal Penelitian dan Pengembangan Pendidikan. Vol. 2 (3) pp. 246-255. 
Artini, Anak Agung Ayu Sri Vidya. 2014. Pengaruh Model Pembelajaran Scramble Berbantuan Media Semi Konkret terhadap Hasil Belajar IPS Siswa Kelass V SD Gugus Kapten Kompiang Sujana Denpasar Barat Tahun Ajaran 2013/2014. E-Journal PGSD Undiksha, Vol: 2 No: 1 Tahun 2014.

Astuti, Ni Kd. Widi, I Kt. Gading , Dw. Nym. Sudana. 2017. Pengaruh Model Pembelajaran Kooperatif Tipe Scramble Berbantuan Mind Mapping Terhadap Hasil Belajar IPS. eJournal PGSD Universitas Pendidikan Ganesha Mimbar PGSD Vol: 5 No: 2.

Burhandudin, S. d. (2017). Keefektifan Model Pembelajaran Kooperatif Tipe Scramble Dalam Keterampilan Menulis Kalimat Bahasa Jerman Siswa Kelas XI SMA Negeri 11 Makasar. Jurnal pendidikan , 1.

Citrasmi, N.W. 2016. Pengaruh Model Pembelajaran Scramble Berbantuan Media Gambar Terhadap Hasil Belajar IPA Kelas IV di SD Negeri 1 Semarapura Tengah Kecamatan Klungkung Tahun Pelajaran 2016/2017. E-Journal PGSD Universitas Pendidikan Ganesha, Vol.4, No.1.

Deviana, Ni Luh Novita, I Wayan Wiarta, Komang Ngurah Wiyasa. 2017. Model Pembelajaran Kooperatif Tipe Scramble Berbantuan Bahan Manipulatif Berpengaruh Terhadap Kompetensi Pengetahuan Matematika. Journal Educatonal Technology Universitas Pendidikan Ganesha Volume 1 Nomor 2. Di akses melalui https://ejournal.undiksha.ac.id/index.php/JET/article/view/11775

Farida, Umul, Ferina Agustini, Husni Wakhyudin. 2017. Efektivitas Model Pembelajaran Scramble Berbasis Kontekstual Terhadap Kemampuan Berpikir Kritis IPS Siswa Kelas III SD Negeri Kebondalem 01 Batang. Jurnal Ilmiah Sekolah Dasar Universitas Pendidikan Ganesha. Vol.1 (3) pp. 192-199.

Himawati, Azizah, dkk. 2017. Penerapan Model Pembelajaran Kooperatif Tipe Scramble Dalam Pembelajaran Keterampilan Menulis Pantun Pada Siswa Sekolah Dasar. Jurnal Didaktika Dwija Indria. Vol.3, No.5.

llyas, Muhamad. 2014. Pembelajaran Matematika melalui Model Kooperatif Tipe Make a Match dan Tipe Scramble Pada Siswa Kelas VII SMP Negeri 4 Palopo. Jurnal IImu Pengetahuan Alam. Vol. 3, No. 1.

Kahfi, Khairul. 2013. Penerapan Model Pembelajaran Kooperatif Tipe Scramble Untuk Meningkatkan Aktivitas Dan Hasil Belajar Siswa Pada Mata Pelajaran Biologi Kelas Viiib Di Smp Negeri 2 Kediri Kabupaten Lombok Barat Tahun Ajaran 2013/2014. Universitas Mataram Repositori

Rakhmawati. 2012. "Penggunaan Model Pembelajaran Scramble Untuk Peningkatan Motivasi Belajar IPA (Fisika) pada Siswa SMP Negeri 16 Purworejo Tahun Pelajaran 2011/2012". Jurnal Pendidikan Fisika Universitas Muhammadiyah Purworejo, Vol. 1, No. 1.

Ramadani. 2014. "Pengaruh Model Pembelajaran Scramble Berbantuan Kartu Pertanyaan Terhadap Hasil Belajar IPA Siswa Kelas V SD". E-Journal Mimbar PGSD Universitas Pendidikan Ganesha, Vol. 2, No. 1.

Samatowa, U. (2010). Pembelajaran IPA di Sekolah Dasar. Jakarta: Permata Puri Media.

Samatowa, u. (2016). Pembelajaran IPA di Sekolah Dasar. Jakarta: PT Indeks. 
Saridewi, N..P. 2017. Penerapan Model Pembelajaran Scramble untuk Meningkatkan Hasil Belajar IPA Siswa Kelas IV Semester I SD No. 3 Legian Tahun Pelajaran 2016/2017. Jurnal PGSD Universitas Pendidikan Ganesha, Vol. 1, No. 3.

Sugiono. (2017). Metode Penalitian Pendidikan Pendekatan Kuantitatif, Kualitatif, dan RND.Bandung: Alfabeta.

Suliadi, Ilham dkk. 2017. Pengaruh Penerapan Model Pembelajaran Kooperatif Tipe Scramble Terhadap Hasil Belajar Siswa Pada Materi Hidrokarbon di Kelas X SMA Negeri 8 Palu. Jurnal akademik Kimia. Vol.6, No.4.

Susanto, P. (2018). Belajar Tuntas. Jakarta: PT Bumi Aksara.

Sya'ban, V. M. (2016). Pengaruh Metode Scramble Terhadap Minat Belajar IPS Siswa Kelas V SDN Rejowinangun 1 Yogyakarta. jurnal pendidikan guru sekolah dasar , 25.

Zain, S. B. (2010). Strategi Belajar Mengajar. Jakarta: Rineka Cipta 